\title{
Does it Matter to be Informal? Type of employment and political opinions in the MENA region
}

\author{
Anil Duman \\ Central European University \\ dumana@ceu.edu
}

\begin{abstract}
Informal activities are highly persistent in developing countries, and their economic effects are widely studied in the literature. Yet, political consequences of informality are relatively an understudied topic and big chunk of the existing work does not offer systematic examination of how informal sector participation shape preferences and attitudes. Our paper contributes to the literature by focusing on Arab countries that have very stable and large size of informal sectors in the world. Additionally, we take into account the endogeneity between informal employment and citizens' perceptions about corruption, trust and government's performance by adopting an IV estimation strategy. We argue that working in the informal sector has a negative impact on how individuals view government's performance even after controlling for a battery of socio-economic characteristics. Our findings reveal that both narrow and broader definition of informal employment in the MENA region is significantly increasing the likelihood of adverse perceptions. Individuals in the informal sector are more skeptical about government's performance in job creation and redistribution. Also, their level of trust for political actors are lower and they declare greater levels of corruption. Moreover, we demonstrated that the impact is not conditional on incomes and even respondents belonging to high income households in the MENA region evaluate the government more negatively if they are in the informal sector. Our results are robust to sampling, recoding variables, and model selection.
\end{abstract}

Keywords: informal, employment, MENA, corruption, trust, job creation, redistribution, remittances, endogeneity, instrumental variable 


\section{Introduction}

Informal activities are highly persistent in developing countries, and their economic effects are widely studied in the literature. Yet, political consequences of informality are relatively an understudied topic in social sciences, and big chunk of the existing work does not offer systematic examination of how informal sector participation shape preferences and attitudes. The relationship between an individual in the informal sector and state is expected to be highly distinct from the formal sector counterparts as the work and income of the former are outside the regulatory and protective framework. This looser attachment to state and its existing institutions can be either voluntary or involuntary, and the distinction establishes the basis of the well-known theoretical approaches to informality. Regardless of the difference in conceptualization of informality and subsequent measurements, it has been a fundamental part of the economy and livelihoods of large segments of the population across the world as well as in the Middle East and Northern African (MENA) region.

As opposed to the theoretical expectations of informal economic activities shrinking with development and modernization, there is no clear evidence of reduction in many countries. In most emerging and developing economies, informal employment remains to be around 44\%, although some of these economies have experienced high rates of growth and institutional transformations over the last three decades (World Bank, 2019). Similarly, informality is quite extensive and persistent in the MENA region, which suggests that it can be a salient factor in determining people's opinions about certain policies and preferences. While the causes and consequences of informal labor have been broadly analyzed in the literature, its political implications and particularly the variation of policy preferences within informal sector participants have received less attention. Not only informal sector participants can have different policy preferences in comparison to their formal sector workers, but they also might greatly vary depending on how well or worse-off they are in these positions.

There are two main objectives of this paper, first, policy preferences and opinions of formal and informal sector participants in a number of MENA countries are examined ${ }^{\mathrm{i}}$. As mentioned above, MENA region has one of the highest shares of informal economic activities in the world, and the size of the sector has been quite stable over decades, which suggest that its effects are not ephemeral and can be influential on citizens' perceptions. Besides, the research on informal sector 
in MENA countries is extremely limited, especially with regards to its political consequences. There are few studies that examine the relationship between informality and political attitudes for other regions in the world. It has been shown that labor market dualization is not a significant predictor of social policy preferences and individual level opinions in Latin America (Baker and Velasco-Guachalla, 2018; Berens, 2015a). However, it has been also demonstrated that the size of the informal sector in a country lowers the support of formal sector workers for public welfare goods due to lack of contribution by the informal employees (Berens, 2015b). Even though this research is immensely helpful in understanding the effects of informal work on individual level choices, previous work is mostly concentrated on social policy and welfare programs. Besides, these studies are exclusively focused on Latin America and inclusion of another region, MENA, is useful to check the validity of these arguments and highlight any possible inter-regional differences.

Second objective is to improve the analysis methodologically by considering the endogeneity of informal employment. In the literature, varying reasons, and motivations for people to opt for informal activities have been discussed. These range from level of taxes, administrative and labor regulations, low quality public goods and services, corruption of government officials to lack of trust towards state institutions (De Soto 1989; Lehmann 2012; Gerxhani 1999; Schneider 2007). As can be understood from the list people's opinions about corruption, quality of public services and trust are expected to have an influence on informality. However, the existence and magnitude of informality can also affect these in return since taxation would be lower as a result of informal economic activities. In other words, there is an endogenous relationship between informal employment and political views. We use an instrumental variable strategy to solve the endogeneity due to unobserved confounders. Informal employment is instrumented by the existence of remittances. Remittances increase household income and can reduce labor force participation, especially working under dire conditions such as informal employment.

Our results imply a strong and robust link between informal work and opinions about various issues for several Arab countries. Most of the existing studies inspect the relationship between informality and social policy preferences and concluded that there is no divide across formalinformal employees in Latin America (Berens, 2015b; Baker and Velasco-Guachalla, 2018). Even though we do not test the effect of informality on social policy preferences due to unavailability of data, our findings reveal that informal employment in MENA is explanatory for judgements on 
broad issues such as corruption, trust, job creation and redistribution. These are in line with the previous research on the region, which also pointed out that corruption and lack of trust are major obstacles to formalization (World Bank 2019; Bourhaba and Hamimida, 2016). We extend this literature by taking endogeneity into consideration and show that even after using an instrumental variable technique and controlling for several factors, individuals in the informal sector are more skeptical about government's performance, trust less and announce greater levels of corruption. also, our results indicated that the effect of informality is not conditional on incomes, and even relatively better-off respondents continue to have adverse opinions.

The paper is organized as follows. In the second part, literature on the causes and consequences of informal economic activities, especially in relation to how informal employment and political opinions are linked are summarized. The third section if the paper shows data, descriptive empirical findings from MENA region, and methodology. In the fourth part, discussion of the results is provided. In the final part of the chapter, brief concluding remarks and policy implications are offered.

\section{Theories of Informality and Overview of Informality in MENA}

There are three primary theoretical approaches to informal sector, highlighting various explanations for the existence and persistence of informality. While the modernist school argues that informal sector is a remnant of the traditional production systems and would disappear as the economy progress, the neoliberal approach emphasizes the imperfections in governance and claims that high taxes, corruption and excessive state interventions make economic agents to voluntarily exit the formal sector to minimize their costs of operation (Lewis, 1955; de Soto, 1989). Structuralist perspective, on the other hand, suggests that informal-formal divide is tenuous since informal enterprises are functionally integrated into the global value chains via subcontracting and outsourcing. People work in these largely unregulated and poorly paid jobs because they are excluded from the formal sector (Castells and Portes, 1989; Davis, 1994). Empirical studies reveal mixed evidence for each approach as there is no secular decline in informal employment with economic development. Moreover, corruption and quality of governance indicators are not fully explanatory for the variance across countries. And despite the importance of social protection for 
the most vulnerable groups, demographic, occupational and regional features remain to have profound effects on informal employment (Chen, 2012; Kanbur, 2017; Duman, 2020).

According to modernization school, there are rigid divisions between formal and informal activities. With productivity gains and technological upgrading, informal sector is expected to get smaller, and the duality of the economic structure would recede with industrialization and urbanization (Lewis, 1955; Portes and Hoffman, 2003). However, empirical support for dualism is rather weak and informal economy remains to be persistent in various countries even when they experience growth and higher income levels. In Latin America, Africa and Arab countries, informal sector makes up almost $50 \%$ of the economy, and over time there is no secular decline in its size and even some increase across several countries. For example, it has been found that informality expanded in Egypt over the last twenty years both because of very limited mobility between the sectors and increased risks of unemployment among the formally employed (Elsayed and Wahba, 2019).

At the macro level, there are a number of reasons behind the tenacity of informal sector such as economic and political turmoil, long lasting inequalities, and mixture of low-quality institutions and weak enforcement. In line with the neoliberal approach to informality, which focuses on governance imperfections, empirical literature demonstrates that the association between the size informal economic activities and regulatory burden is positive. Additionally, tax evasion is higher in countries that have above average rates and weak enforcement, which can be taken as another marker of informality (Vuletin, 2008; Ordonez, 2014). For example, corruption is argued to be one of the biggest obstacles against formalization in non-Gulf countries of MENA region, and survey evidence shows that level of trust to governments are rather low (World Bank 2019). In Morocco, people find taxation extremely burdensome and conceal their earnings to avoid tax payments. The same study also discusses that corruption is another major determinant of why individuals go for informal economic activities (Bourhaba and Hamimida, 2016). Hence, corruption and other deficiencies of governance mechanisms not only harm people's loyalty to the system but they also lower the ability of particular groups in the society to have access to public services.

While inefficiency of bureaucracy and low-quality institutions are prominent for informality, there are also subjective determinants of how people evaluate the performance of states. Noncompliance and disregard of the regulations are contingent on perceptions of effectiveness and fairness of state actions (Hirschman, 1970; Saavedra and Tommasi, 2007). If individuals believe 
that tax and transfer system in a country is ineffective or unfair, they are less likely to contribute and might try to free ride or find alternative solutions to their collective action problems. At the same time, inefficiency of formal institutions and unequal outcomes lead to various individuals to be excluded from the system. Inequality of opportunity as well as lack of access to basic services mean that certain parts of the society are left voiceless and cannot channel their objections to the system through formal means (Perry et al., 2007). As can be understood from these conceptualizations, the factors causing informality to grow, either in the form of exit or exclusion, also alter the relations between people and the state. In view of this, it can be argued that political views and evaluations of informal sector participants would be highly distinct.

Besides the social contract between citizens and states, and perceptions about the functioning of governments, there are material factors affecting the political capacities of formal and informal sector participants. Informal employees are discussed to be less mobilized as their resources are limited and they face greater economic risks Unionization and other types of collective organizations are barely present among the informal sector workers. Thus, bargaining power against employers is extremely low and heavily depends on individual endowments, which elevate the existing inequalities. Like other regions, informality is widespread among younger and uneducated people in MENA countries, which mean that their individual bargaining options are also highly deficient (Angel-Urdinola and Tanabe, 2012). Furthermore, informal sector participants fall outside of the regulatory coverage placing them in even a more disadvantaged status. As a result, their strategies to cope with labor market uncertainties are far more restricted than the formal sector workers. For example, during the latest pandemic, the poorest of the informal employees are hit hardest economically, and at the same time, they are not able to get public assistance or healthcare (Holtmeier and Alami, 2020). Hence, informal sector workers, even when they have similar income levels to their formal counterparts, need to individually insure against labor market risks since they fall outside the scope of social security. It is shown that in MENA region, diversity within the informal sector is crucial as income mediates the relationship between political opinions and type of employment. The likelihood of asserting that corruption is high and possibility of not trusting the government goes down for people in the upper tier of the informal sector (Duman, forthcoming).

In relation to the materially disadvantaged position of informal sector participants, it is argued that mobilization and class identity formation among this group are quite weak. On the one hand, 
informal workers are employed in small firms and self-employed are usually solo proprietors. On the other hand, heterogeneity of informal economic activities and reasons for being in the informal sector cause atomization and lack of shared interests (Baker and Velasco-Guachalla, 2018; Kurtz, 2004). Moreover, it is claimed that a big part of the informal sector consists of petty entrepreneurs, who might oppose to interventionists policies of the state and align with capitalist values (de Soto, 1989). For example, self-employed in Tunisia asserted that they are content with the revenues they generate from their informal economic activities and do not have any incentives to join the formal sector or preference for regulation (Trabelsi, 2013). Also, it is shown that better perceived government performance in the form of corruption control and freer elections in Arab nations increase the support for democracy but clientelistic practices have no such effect (Benstead et al., 2019). These ideational factors and diversity of interests make it difficult for people to unite around common goals and muster enough power to shape policy making. However, implications of scarce mobilization and capitalist values are distinct for the poorer and wealthier segments of the informal sector. The former is likely to suffer from inability to collectively act and does not have the private resources to shield against labor market risks. In contrast, latter group might prefer a hands-off approach due to their entrepreneurial inclinations and support the government policies as they are able to benefit from the system economically.

\section{Data and Methodology}

\subsection{Data Source and Descriptive Statistics}

The primary data source of the paper is the $5^{\text {th }}$ wave of the Arab Barometer, which is a source of high-quality public opinion survey focusing MENA region. This is the most comprehensive and standardized international survey covering a wide range of questions such as the demographic features of the participants, labor market status and views about political institutions, government performance and international relations. The survey was first launched in 2006 and the last wave was conducted in 12 countries between the years of 2018 and 2019. For each country, the survey is nationally representative and covers the citizens of aged 18 and above. Individual is the unit of analysis, who are selected randomly from households and each household is represented only by one individual $^{\mathrm{ii}}$. From the last wave, in total there are 26,780 observations for Algeria, Egypt, Iraq, 
Jordan, Kuwait, Lebanon, Libya, Morocco, Palestine, Sudan, Tunisia and Yemen. Kuwait's classification for occupational status, contract and income is not consistent with the rest of the sample, hence it is dropped from the estimations. Given that informality in Gulf countries ${ }^{\mathrm{iii}}$ is much lower than the other MENA countries due to immigrant labor and public employment, exclusion of Kuwait should not bias the results.

In order to account for public opinion about various issues four different questions are utilized as dependent variables. The first question asks the extent of corruption within the national state agencies and institutions in the respondent's country, and the answers vary between not at all to large extent. For trust, participants are requested to declare their level of trust (a great deal of trust to no trust at all) for a number of institutions including central government, parliament, religious leaders and local government. Arab Barometer deals with economic assessments of the citizens extensively and opinions about government's performance on creating jobs and narrowing the gap between rich and poor are chosen for their relevance for the informal employees. Respondents can rank how the current government is doing from very good to very bad. Table 1 presents the share of responses on each dependent variable. As can be seen, a very noticeable ratio of surveyors, $55.1 \%$, assert that corruption is extensive in their country and $39.5 \%$ of them do not trust their governments. Similarly, negative evaluations of governments with respect to job creation and redistribution are quite high, almost $44 \%$ and $39 \%$ respectively. Table A1 repeats the same exercise by countries. 
Table 1. Share of Responses (\%)

\begin{tabular}{|l|r|}
\hline Corruption: Extent National Level \\
\hline No Extent & 2.66 \\
\hline Small Extent & 11.86 \\
\hline Medium Extent & 30.38 \\
\hline Large Extent & 55.1 \\
\hline Trust: Government & \\
\hline Great Trust & 10.95 \\
\hline Some Trust & 24.72 \\
\hline Little Trust & 24.8 \\
\hline No Trust & 39.53 \\
\hline Creating Job Opportunities & \\
\hline Very Good & 2.71 \\
\hline Good & 16.58 \\
\hline Bad & 37.04 \\
\hline Very Bad & 43.68 \\
\hline Narrowing Gap Between Rich and Poor \\
\hline Very Good \\
\hline Good & 2.87 \\
\hline Bad & 16.57 \\
\hline Very Bad & 41.81 \\
\hline Sour: Aut & 38.74 \\
\hline
\end{tabular}

Source: Author's calculations based on Arab Barometer.

The main independent variable is informal sector employment, which is not easy to operationalize because of data problems and consistency across countries. In the survey, there is a question directly asking about whether the respondents have a contract for their current position if they stated that they are employed. Given the limited availability of data at the international level, the definition of informal economic activities in this chapter is entirely based on the status in the labor market, namely if the employees have contracts or not. Not having a contract as a wage worker means not being able to benefit from social security benefits and at best little protection by the legal framework. There are several researchers who also adopt the same definition of informal employment and categorize workers according to their registration into social security and legal protections offered by contractual relations (Acar and Tansel, 2016; Hussmanns, 2005). Selfemployed is also included as an additional measure of informality for robustness checks ${ }^{\mathrm{iv}}$. As can be seen from Figure 1, informal employment measured by not having a contract is very prevalent in the region where the average is more than 50\%. Even though the ratio is well above the developed country levels, it is still comparable to various economies in Asia and Africa. 
Figure 1. Share of Employees with No Contract and Self-Employed



Source: Author's calculations based on Arab Barometer

There is also a lot of variation within the region as informal employment oscillates between nearly $7 \%$ in Morocco to almost $58 \%$ in Libya. In addition, the proportion of self-employment, which is sometimes taken as a proxy for informal sector, is around $43 \%$ on average. Once again, there are important differences among MENA countries where the share of self-employed is 56\% in Morocco and approximately 13\% in Libya. Figure A1 exhibits share of informal, formal and self-employment, unemployment and inactive across countries. These figures are very much in line with previous studies on the region, which show that some of these economies represent the most informal economies in the world (Loayza and Wada, 2011). Particularly, in countries with larger agricultural employment such as Morocco and Libya, total number of informal sector employees is much higher. In contrast, urbanization and bigger public sectors in Egypt and Lebanon reduce the proportion of informal economic activities in these economies (AngelUrdinola and Tanabe, 2012). However, on average informal sector is very sizable and persistent in MENA region, which makes it a relevant factor for the differences in policy preferences and opinions.

Additionally, a list of control variables is included in the estimations, which are common to the literature and allow our findings to be comparable to the previous studies. These are age, gender, highest level of education attained, marital status, residing in rural area, number of 
employed people in the household and religiosity (Baker and Velasco-Guachalla, 2018; Berens, 2015a; Berens, 2015b). Since the survey does not have a question on political ideology, a variable is formed, statists, based on responses about the necessity of citizens supporting the government's decisions, even if they disagree with them. Individuals who agree with this statement are expected less likely to challenge governments' decisions and performance. Moreover, existence of remittances is included as an instrumental variable, which is described in further detail in the following section. Table 2 exhibits the share of covariates by formal, informal and selfemployment. It is clear that there are no major differences with respect to age, religiosity, statism, and location of residency. However, self-employed are mostly male, have lower education than both informal and formal workers, and their evaluation of job creation and redistribution are more adverse. Informal workers, on the other hand have lower average incomes and report greater corruption and lower trust. In Table A2 we present the summary statistics for all variables.

Table 2. Share of Covariates by Employment Type

\begin{tabular}{|l|c|c|c|}
\hline & Formal & Informal & Self-Employed \\
\hline Corruption: Extent National Level & & & \\
\hline Large Extent & 58.89 & 63.09 & 56.12 \\
\hline Medium Extent & 27.03 & 26.36 & 30.14 \\
\hline Small Extent & 12.03 & 8.63 & 11.32 \\
\hline No Extent & 2.04 & 1.92 & 2.42 \\
\hline Trust: Government & & & \\
\hline Great Trust & 13.26 & 7.73 & 9.64 \\
\hline Some Trust & 23.49 & 20.54 & 21.73 \\
\hline Little Trust & 25.55 & 24.38 & 26.19 \\
\hline No Trust & 37.69 & 47.34 & 42.44 \\
\hline Creating Job Opportunities & & & \\
\hline Very Good & 3.11 & 2.83 & 2.03 \\
\hline Good & 18.22 & 15.61 & 12.81 \\
\hline Bad & 37.51 & 39.66 & 37.36 \\
\hline Very Bad & 41.17 & 41.91 & 47.80 \\
\hline Narrowing Gap Between Rich and Poor & & & \\
\hline Very Good & 2.62 & 2.72 & 2.13 \\
\hline Good & 18.18 & 14.20 & 14.41 \\
\hline Bad & 40.98 & 41.86 & 40.21 \\
\hline Very Bad & 38.22 & 41.22 & 43.25 \\
\hline Education & & & \\
\hline No Education & 1.29 & 2.05 & 7.49 \\
\hline
\end{tabular}




\begin{tabular}{|l|c|c|c|}
\hline Primary & 10.00 & 17.54 & 31.86 \\
\hline Secondary & 19.16 & 18.59 & 30.00 \\
\hline High & 12.94 & 19.07 & 10.90 \\
\hline University and above & 56.62 & 42.75 & 19.75 \\
\hline Gender & & & \\
\hline Male & 64.47 & 67.41 & 86.17 \\
\hline Female & 35.53 & 32.59 & 13.83 \\
\hline Married & & & \\
\hline Not Married & 33.17 & 29.03 & 33.40 \\
\hline Married & 66.83 & 70.97 & 66.60 \\
\hline Rural & & & \\
\hline Urban & 75.75 & 77.53 & 68.43 \\
\hline Rural & 24.25 & 22.47 & 31.57 \\
\hline Statist & & & \\
\hline Statist & 63.77 & 64.90 & 62.99 \\
\hline Not Statist & 36.23 & 35.10 & 37.01 \\
\hline Religious & & & \\
\hline Religious & 67.17 & 66.52 & 69.52 \\
\hline Not Religious & 32.83 & 33.48 & 30.48 \\
\hline Remittances & & & \\
\hline Receive & 88.72 & 92.06 & 88.18 \\
\hline Do not Receive & 11.28 & 7.94 & 11.82 \\
\hline Mean Age & 36.95 & 38.43 & 39.48 \\
\hline Mean Income Category & 7.84 & 6.43 & 7.44 \\
\hline Mean \# of Employed in the HH & 1.98 & 1.88 & 1.94 \\
\hline Sourc: Aut & & \\
\hline
\end{tabular}

Source: Author's calculations based on Arab Barometer

\subsection{Econometric Methodology}

Individuals' view on corruption, trust, job creation and redistribution in the survey are measured on an ordinal scale with an ascending order; thus, using the regular ordinary least squares model may lead to biased results. Thus, we employ ordered probit method to explore the impact of informal employment on opinions. For robustness checks, we also recoded the dependent variables based on the least favorable answers and run probit regression with binary values ${ }^{\mathrm{v}}$. The main equation to be estimated is as follows: 


$$
\begin{gathered}
O p_{i}^{*}=\alpha I_{i}+X_{i}^{\prime} \beta+\varepsilon_{i} \\
O p_{i}=\left\{\begin{array}{c}
1 \text { if } O p_{i}^{*}<r_{1} \\
2, \text { if } r_{1}<O p_{i}^{*}<r_{2} \\
3, \text { if } r_{2}<O p_{i}^{*}<r_{3} \\
4, \text { if } r_{3}<O p_{i}^{*}
\end{array}\right\}
\end{gathered}
$$

$O p_{i}$ refers to the four different dependent variables used in the paper; opinions about extent of corruption, degree of trust, evaluation of job creation performance, and assessment of government in terms of narrowing the gap between rich and poor. $O p_{i}^{*}$ denotes the latent variable of views in Equation (1). The key explanatory variable, $I_{i}$ is a binary variable indicating whether the individual is working in the informal sector, which is captured by the absence of a contract. $X_{i}^{\prime}$ is a vector of demographic and socioeconomic variables, $\varepsilon_{i}$ is a normally distributed error term in the equation and $i$ denotes an individual respondent. $r_{j}(\mathrm{j}=1,2,3)$ are the thresholds (cut-off points) to be estimated with the restriction of $r_{1}<r_{2}<r_{3}$.

As mentioned in the previous sections, there can be potentially endogeneity between informal employment and opinions about government. Hence, we use an instrumental variable strategy for the above ordered probit model (IV ordered probit). Remittance is employed as the instruments in our study, which both satisfy the requirements of relevance ${ }^{\mathrm{vi}}$ and exogeneity for an effective IV. Figure A2 displays the share of remittance beneficiaries and individuals who do not receive by country. It can be observed that except Yemen and Morocco, the distributions are quite similar. In the literature, the connection between remittances and labor force participation and work is extensively researched. On the one hand, it is argued that remittances increase the household income and discourage people to participate in informal labor markets (Justino and Shemyakina, 2012). On the other hand, remittances can provide the necessary capital to start a small business or work as self-employed (Posso, 2012). It has been also suggested that at the regional level, remittances increase the likelihood of informal work among non-migrant households (Ivlevs, 2016). Also, remittances do not have a direct influence on the views about corruption, trust, job creation and redistribution, and are only indirectly related to the dependent variable through changing informality. The first and second stage equations are as follows: 


$$
\begin{aligned}
& I_{i}^{*}=\gamma R_{i}+Z_{i}^{\prime} \theta+\varphi_{i} \\
& I_{i}=\left\{\begin{array}{l}
0, \text { if } I_{i}^{*}<0 \\
1, \text { if } I_{i}^{*} \geq 0
\end{array}\right\} \\
& O p_{i}^{*}=\alpha^{*} \widehat{I}_{l}+X_{i}^{\prime} \beta+\varepsilon_{i}
\end{aligned}
$$

Where $I_{i}^{*}$ is the latent variable for informal employment in Equation (3), $R_{i}$ represents the instrumental variable for remittances an $Z_{i}^{\prime}$ is the vector including age, gender, location of residence, education, and number of employed persons in the household. $\varphi_{i}$ is a normally distributed error term in Equation (3), and $\widehat{I}_{l}$ is the fitted value of informal employment estimated in the first stage. Finally, $\alpha^{*}$ is the coefficient of interest, which is a consistent estimate after substituting $\widehat{I}_{l}$ into Equation (5). The ordinal nature of the endogenous variables presented a "forbidden regression" problem in the first stage (Angrist and Pischke, 2008). Therefore, we used the extended ordered probit regression that accommodates ordinal endogenous covariates while implementing the maximum likelihood estimator (Wooldridge, 2010).

There are numerous tests to test the relevance and strength of the instrumental variable with 2SLS. First, Kleibergen-Paap is computed for weak identification, which looks at whether the excluded instruments are sufficiently correlated with the endogenous regressor. In the literature, rule of thumb for weak identification is an F-statistics that is smaller than 10. In the next step, we consider overidentification and check the correlation of the instrument with the error term, which is also known as Hansen test. Finally, we look at the endogeneity by Sargan-Hansen statistics. Since our endogenous regressor and instrumental variable are both binary, using 2SLS might not be recommended. Thus, we check the validity of our IV strategy with bivariate probit estimations and test if the correlation of the error terms of the two probit regressions is significantly different from zero. When the null hypothesis of no correlation between the two error terms is rejected, bivariate probit model is applicable, and informal employment is endogenous to our dependent variables, and receipt of remittances is a proper instrument ${ }^{\mathrm{vii}}$. 


\section{Results and Discussion}

\subsection{Informal Employment and Public Opinions}

Table 3 presents the relationship between informal employment and opinions about corruption and trust. In the $1^{\text {st }}$ and $3^{\text {rd }}$ columns, estimation results before controlling for endogeneity are shown. $2^{\text {nd }}$ and $4^{\text {th }}$ column demonstrate the impact of informality after we consider the endogeneity. As can be seen from the below table, informal work in the MENA region is positively and significantly related to political views, namely extent of corruption and level of trust. For both dependent variables, being in the informal sector increases the likelihood of adverse opinions. The findings are verified with the instrumental variable method too, and once the endogeneity is taken care of, the coefficient on informal employment goes up for both dependent variables. For corruption, the likelihood of asserting negative views by an informal worker increases more after informal employment is instrumented. Similarly, informal respondents are less likely to trust when endogeneity issues are considered. The correlations between the errors from the selection equation and the errors from the main equation are -0.6 and -0.68 for corruption and trust, respectively. These are significantly different from zero, so we confirm our suspicion of endogeneity. Because it is negative, we conclude that unobservable factors that increase the chance of informal employment tend to reduce the chance of reporting less adverse views. 
Table 3. Informal Employment, Corruption and Trust

\begin{tabular}{|c|c|c|c|c|}
\hline & Corruption & Corruption (IV) viii & Trust & Trust (IV) \\
\hline \multirow[t]{2}{*}{ Informal } & $0.08^{*}$ & $1.05 * *$ & $0.10 * *$ & $1.19 * *$ \\
\hline & $(0.03)$ & $(0.16)$ & $(0.03)$ & $(0.13)$ \\
\hline \multirow[t]{2}{*}{ Age } & 0 & 0 & 0 & 0 \\
\hline & $(0.00)$ & $(0.00)$ & $(0.00)$ & $(0.00)$ \\
\hline \multirow{2}{*}{ Gender } & 0.02 & -0.04 & 0 & $-0.09 *$ \\
\hline & $(0.03)$ & $(0.04)$ & $(0.03)$ & $(0.04)$ \\
\hline \multirow[t]{2}{*}{ Primary } & $0.33 * *$ & $0.24^{*}$ & $0.41 * *$ & 0.19 \\
\hline & $(0.08)$ & $(0.12)$ & $(0.09)$ & $(0.12)$ \\
\hline \multirow[t]{2}{*}{ Secondary } & $0.30 * *$ & 0.17 & $0.24 * *$ & 0.09 \\
\hline & $(0.08)$ & $(0.11)$ & $(0.09)$ & $(0.12)$ \\
\hline \multirow[t]{2}{*}{ High } & $0.47 * *$ & 0.17 & $0.43 * *$ & 0.09 \\
\hline & $(0.08)$ & $(0.13)$ & $(0.09)$ & $(0.13)$ \\
\hline \multirow[t]{2}{*}{ University } & $0.48 * *$ & $0.28^{*}$ & $0.33 * *$ & 0.06 \\
\hline & $(0.08)$ & $(0.13)$ & $(0.09)$ & $(0.13)$ \\
\hline \multirow[t]{2}{*}{ Married } & 0.02 & 0 & -0.03 & -0.05 \\
\hline & $(0.03)$ & $(0.04)$ & $(0.03)$ & $(0.04)$ \\
\hline \multirow[t]{2}{*}{ Rural } & $-0.11^{* *}$ & -0.01 & $-0.25 * *$ & $-0.19 * *$ \\
\hline & $(0.03)$ & $(0.04)$ & $(0.03)$ & $(0.04)$ \\
\hline \multirow[t]{2}{*}{ Statist } & $-0.53^{* *}$ & $-0.50 * *$ & $-0.73 * *$ & $-0.64 * *$ \\
\hline & $(0.03)$ & $(0.04)$ & $(0.03)$ & $(0.04)$ \\
\hline \multirow[t]{2}{*}{ Religious } & $-0.08 * *$ & $-0.08 *$ & $-0.17 * *$ & $-0.09 * *$ \\
\hline & $(0.03)$ & $(0.04)$ & $(0.03)$ & $(0.03)$ \\
\hline \multirow[t]{2}{*}{ \# of Employed } & 0 & -0.02 & -0.01 & $-0.03^{*}$ \\
\hline & $(0.01)$ & $(0.02)$ & $(0.01)$ & $(0.02)$ \\
\hline \multirow[t]{2}{*}{ Income } & $-0.04 * *$ & $-0.03 * *$ & $-0.03 * *$ & $-0.02 * *$ \\
\hline & $(0.00)$ & $(0.01)$ & $(0.00)$ & $(0.01)$ \\
\hline \# of Obs. & 8146 & 4070 & 8115 & 4058 \\
\hline \multirow[t]{2}{*}{ Corr } & & $-0.6^{* *}$ & & $-0.68 * *$ \\
\hline & & $(0.1)$ & & $(0.08)$ \\
\hline
\end{tabular}

Notes: The reference category is labor market participations who are not informal. Robust standard errors are in parenthesis. ${ }^{* *}$ and $*$ denote statistical significance at the .01 and .05 levels, respectively.

Once endogeneity is taken into account, the marginal effect of informal work on declaring that there is great extent of corruption is $2.4 \%$ points higher, and the same ratio is $1 \%$ for stating that there is no trust. While these effects are small, they are significantly different from zero, and should be assessed jointly with the negative impact of informal employment on positive views. Figure 2 exhibits the marginal effects of informal employment on the worst opinions about corruption and 
trust for each income category. It can be observed that both for corruption and trust, informality has a statistically significant effect across all income categories even though the magnitude is getting smaller as household income rises. Also, it should be noted that the marginal effects are greater for corruption. For the lowest level of incomes, the probability of asserting great extent of corruption is approximately $72 \%$ and decreases to $58 \%$ at the highest level of income for informal employees. Similarly, there is a decline in the effect of informal employment for reporting no trust from almost $50 \%$ for the poorer individuals to nearly $38 \%$ points for the richest individuals. These findings suggest that informality is a pertinent explanatory variable in the MENA region even for relatively well-off respondents, and the negative relationship between working without a contract and opinions cannot be attributed to earnings.

Figure 2. Marginal Effects of Informality on Corruption and Trust across Income

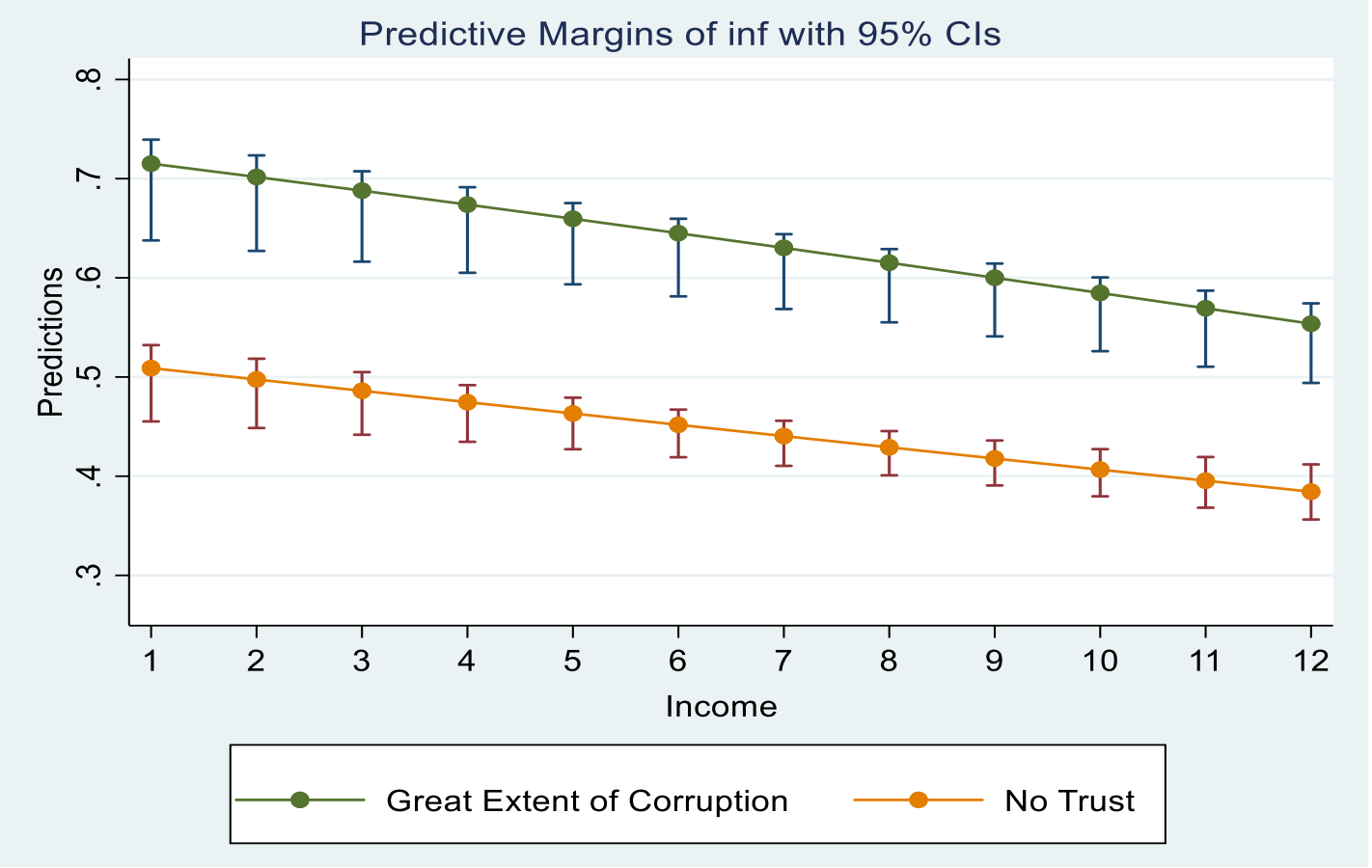

Source: Marginal effects are estimated at covariate means and based on the $2^{\text {nd }}$ and $4^{\text {th }}$ specifications of Table 3 . The outcome level (4) is great extent of corruption and no trust.

In Table 4, evaluation of government's performance for job creation and narrowing the gap between rich and poor as used as dependent variables. Parallel to our findings above, there is a negative relationship between informal employment and people's judgments about government performance. While without instrumental variable, the coefficient on informality is 0.14 and 0.1 
for job creation and redistribution respectively, these rise to 1.12 and 0.74 points after endogeneity is regarded. Hence, in the MENA region, being an informal worker significantly and negatively affects the perceptions about government performance with regards to labor market and inequality. Nevertheless, it should also be noted that the coefficient on informality for evaluation of government performance on narrowing the gap between rich and poor is not robust across specifications and turns out to be significant at $90 \%$ confidence interval. The correlations between the errors from the selection equation and the errors from the main equation are -0.76 and -0.45 , which are significantly different from zero, supporting the existence of an endogenous relationship between informality and public opinions. And given the negative sign of the correlations of error terms, it can be said that unobservable factors that increase the chance of informal employment are likely to decrease the chance of reporting less adverse views.

Table 4. Informal Employment, Job Creation and Redistribution

\begin{tabular}{|c|c|c|c|c|}
\hline & $\begin{array}{c}\text { Job } \\
\text { Creation } \\
\end{array}$ & $\begin{array}{c}\text { Job Creation } \\
\text { (IV) }\end{array}$ & Redistribution & $\begin{array}{c}\text { Redistribution } \\
\text { (IV) }\end{array}$ \\
\hline \multirow[t]{2}{*}{ Informal } & $0.14 * *$ & $1.12 * *$ & 0.01 & $0.74 *$ \\
\hline & $(0.03)$ & $(0.12)$ & $(0.03)$ & $(0.36)$ \\
\hline \multirow[t]{2}{*}{ Age } & 0 & $-0.01 * *$ & 0 & 0 \\
\hline & $(0.00)$ & $(0.00)$ & $(0.00)$ & $(0.00)$ \\
\hline \multirow[t]{2}{*}{ Gender } & -0.05 & $-0.12 * *$ & $-0.08 * *$ & $-0.15 * *$ \\
\hline & $(0.03)$ & $(0.04)$ & $(0.03)$ & $(0.04)$ \\
\hline \multirow[t]{2}{*}{ Primary } & $0.39 * *$ & 0.15 & $0.42 * *$ & $0.38 * *$ \\
\hline & $(0.07)$ & $(0.11)$ & $(0.08)$ & $(0.14)$ \\
\hline \multirow[t]{2}{*}{ Secondary } & $0.28 * *$ & 0.02 & $0.34 * *$ & $0.28 *$ \\
\hline & $(0.07)$ & $(0.11)$ & $(0.08)$ & $(0.14)$ \\
\hline \multirow[t]{2}{*}{ High } & $0.30 * *$ & -0.11 & $0.32 * *$ & 0.18 \\
\hline & $(0.08)$ & $(0.12)$ & $(0.08)$ & $(0.16)$ \\
\hline \multirow[t]{2}{*}{ University } & $0.26 * *$ & -0.11 & $0.35 * *$ & 0.2 \\
\hline & $(0.07)$ & $(0.11)$ & $(0.08)$ & $(0.16)$ \\
\hline \multirow[t]{2}{*}{ Married } & $-0.06^{*}$ & $-0.08^{*}$ & $-0.11 * *$ & $-0.13 * *$ \\
\hline & $(0.03)$ & $(0.03)$ & $(0.03)$ & $(0.04)$ \\
\hline \multirow[t]{2}{*}{ Rural } & $-0.08 * *$ & 0.07 & $-0.13 * *$ & $-0.11 *$ \\
\hline & $(0.03)$ & $(0.04)$ & $(0.03)$ & $(0.05)$ \\
\hline \multirow[t]{2}{*}{ Statist } & $-0.57 * *$ & $-0.45 * *$ & $-0.59 * *$ & $-0.55^{* *}$ \\
\hline & $(0.03)$ & $(0.04)$ & $(0.03)$ & $(0.05)$ \\
\hline \multirow[t]{2}{*}{ Religious } & -0.03 & 0.01 & $-0.14 * *$ & $-0.10 * *$ \\
\hline & $(0.03)$ & $(0.03)$ & $(0.03)$ & $(0.04)$ \\
\hline \# of Employed & 0 & -0.03 & -0.02 & -0.03 \\
\hline
\end{tabular}




\begin{tabular}{|l|c|c|c|c|}
\hline & $(0.01)$ & $(0.02)$ & $(0.01)$ & $(0.02)$ \\
\hline Income & -0.01 & 0 & 0 & 0 \\
\hline & $(0.00)$ & $(0.01)$ & $(0.00)$ & $(0.01)$ \\
\hline & & & & \\
\hline \# of Obs. & 8830 & 4416 & 8581 & 4295 \\
\hline Corr & & $-0.76^{* *}$ & & $-0.45^{*}$ \\
\hline & & $(0.07)$ & & $(0.21)$ \\
\hline
\end{tabular}

Notes: The reference category is labor market participations who are not informal. Robust standard errors are in parenthesis. ${ }^{* *}$ and $*$ denote statistical significance at the .01 and .05 levels, respectively.

Before we move on to the marginal effects across income, it is worthy to mention that the discrete change from non-informal to informal category. With regards to job creation, the likelihood of assessing the government very badly increases by $8 \%$ and for redistribution, it goes up by $2.3 \%$. When the predictors are set to their mean values, it can be seen from Figure 3 that the impact of informality is quite comparable on views about job creation and redistribution. For the lowest income category, the chances of evaluating the government most negatively on each of these policies for an informal job holder is a little below $40 \%$. The effect increases slightly with income and for richer individuals that have informal employment, declaring adverse opinions go up slightly above $40 \%$. Hence, it can be construed that in MENA region, the relationship between informal work and how people appraise government policy on broad economic areas is not explained by their level of earnings. Both poorer and wealthier respondents hold negative views when they are part of informal sector. 
Figure 3. Marginal Effects of Informality on Job Creation and Redistribution across Income

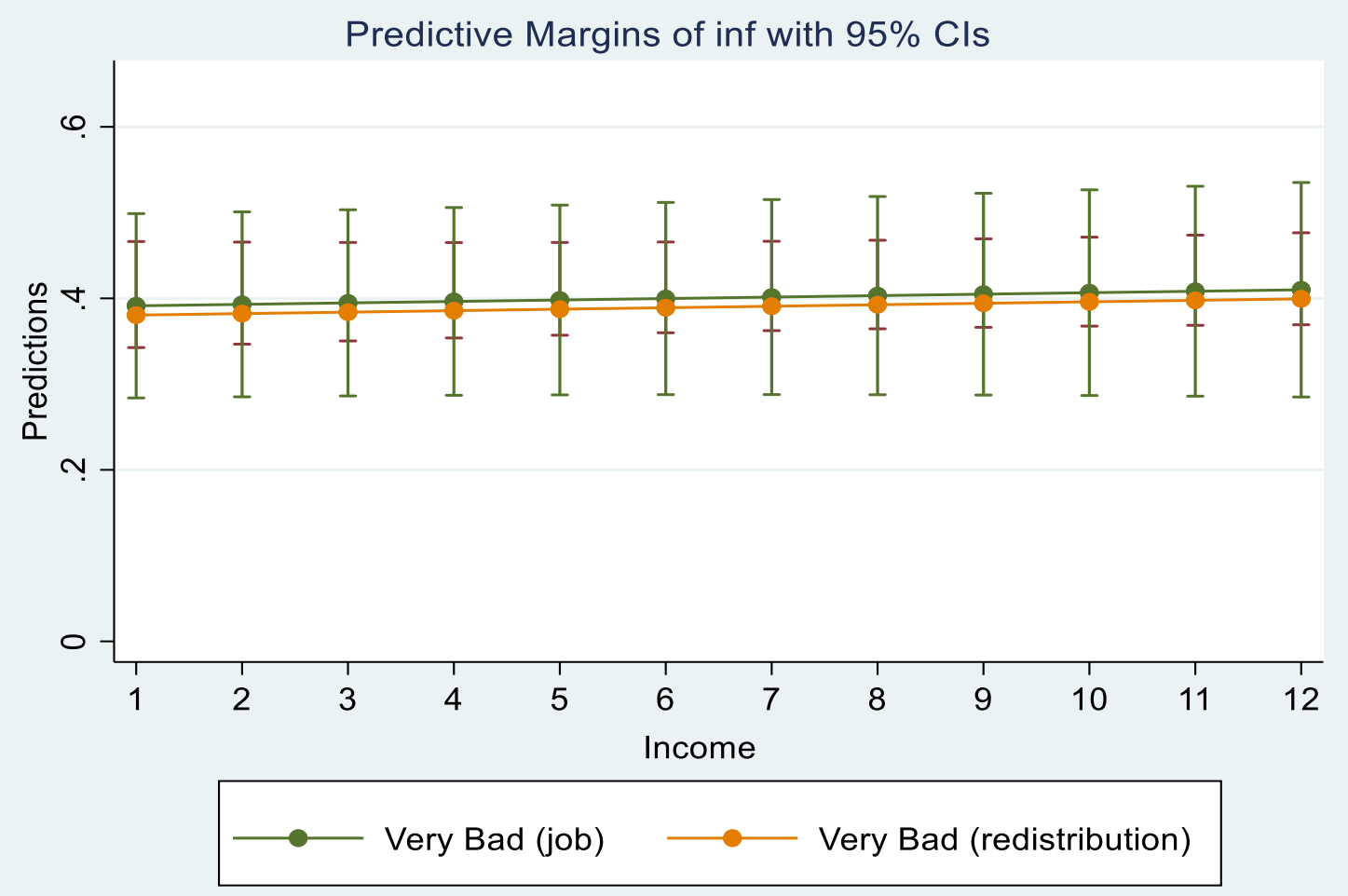

Source: Marginal effects are estimated at covariate means and based on the $2^{\text {nd }}$ and $4^{\text {th }}$ specifications of Table 4 . The outcome level (4) is very bad for job creation and very bad for narrowing the gap between rich and poor.

\subsection{Robustness Checks}

To check the robustness of our findings we first exclude the outlier country that have the most divergent composition of employment. As can be seen from Figure A1 in the Appendix, Libya stands out in terms of its highest share of workers without a contract, almost $31 \%$. We rerun the regression by dismissing the Libyan observations. We also resample by only including the countries that have observations on all variables ${ }^{\mathrm{ix}}$. Both of these estimation results are provided in Table A5 in the Appendix. Informal employment remains to be explanatory in each sample, and negatively affect the opinions on corruption and trust as well as evaluations for job creation and redistribution. For example, the coefficient on informality ranges from 0.87 to 1.27 when Libya is left out due to its extensive ratio of informal workers. The coefficient on informality continues to be positive and statistically significant when Algeria and Yemen are excluded to have the same set of countries across all dependent variables. While the magnitude of informal employment's effect 
stays at 0.74 for redistribution, it increases to 1.19 for trust. Therefore, our results are not driven by the outliers or having different countries in the overall sample across dependent variables.

In the next step we expand the definition of informality to incorporate self-employment. A big fraction of self-employed in developing countries is unregistered either at the firm level or through social security (Duman, 2020). Hence, part of self-employed is often categorized as informal but given the lack of data on registry, we are unable to distinguish between formal and informal selfemployment for the MENA region. By adding self-employed to workers without contracts, a new measure for informality is constructed. In Figure A2 and A3, we present the marginal effects of the broad definition of informal employment on the worst opinions about corruption, trust, job creation and redistribution. As can be seen, when self-employment is included, still informality raises the negative attitudes, especially for trust and corruption. The marginal effect of informal employment on stating that there is no trust is nearly $47 \%$ or in other words $5.8 \%$ higher than an individual in the formal economy. For the most adverse evaluation of government performance with regards to job creation and redistribution, marginal effect of informality is almost $2.5 \%$ higher. As a result, we deduce that our findings are robust and not contingent on the definition of informal work.

We also recoded the dependent variables and formed a binary response by bulking the most negative and negative assessments together. Table A6 in the Appendix demonstrates the estimation output, and it can be seen that informal employment has positive and statistically significant coefficient across all dependent variables. The likelihood of declaring large and medium extent of corruption is 1.28 points higher for informal sector participants while for little and no trust, the magnitude is 1.1 points. For economic issues, the coefficient of informal employment goes up when the dependent variables are utilized, 1.83 and 1.81 for job creation and redistribution, respectively. When these are translated into marginal effects, informality raises the probability of asserting corruption by almost $3.5 \%$ and for not trusting the government, the ratio is $1 \%$. In terms of very poor and poor evaluation of government performance with regards to job creation and redistribution, marginal effects of informal work are $2 \%$ and $1 \%$, respectively. These verify our earlier findings, and hence the negative relationship between political opinions and informal employment in the MENA region is robust and to a certain extent independent of the sampling, measurement, and coding problems. 


\section{Conclusion}

Informal economic activities constitute a large part of production and exchange in various countries including the ones in MENA. Besides, informal economic activities are extremely resilient, which suggest that the effects of informality are not necessarily temporary. Previous studies looking at informality in the region are relatively scarce for the region, and they mostly consider macro level factors determining the size of informal sector or micro level characteristics behind informal employment. The research on informal sector in MENA countries is extremely limited, especially with regards to its political consequences. Our paper contributed to the literature by focusing on Arab countries that have very stable and large size of informal sectors in the world. Additionally, we take into account the endogeneity between informal employment and citizens' perceptions about corruption, trust and government's performance. In the literature, these factors are often examined to understand the motivations for going informal, nonetheless, the relationship between informality, policy and opinions can run in the opposite direction. Our paper adopted an instrumental variable strategy to control for endogeneity.

We argued that working in the informal sector has a negative impact on how individuals view government's performance. Specifically, we showed that both the narrow and broader definition of informal employment in the MENA region is significantly increasing the likelihood of adverse perceptions. In contrast to the research focusing on Latin America, our empirical examination revealed that informality is a major determinant of opinions on various political and economic issues. Individuals in the informal sector are more skeptical about government's performance in job creation and redistribution. Also, their level of trust for political actors are lower and they declare greater levels of corruption. Moreover, we demonstrated that the impact is not conditional on incomes and even respondents belonging to high income households in the MENA region evaluate the government more negatively if they are in the informal sector. Our results are robust to sampling, recoding variables, and model selection.

Even though we employed several methodological extensions to provide unbiased estimates, few limitations remain. First, we are unable to control for time invariant heterogeneity since our data set is cross-sectional. Clearly, unobserved characteristics can alter people's willingness to have informal employment and their beliefs about political and economic questions. However, there is no panel data for Arab countries that have data on informality and opinions, and Arab 
Barometer is one of the highest quality international surveys concentrating on the region. Another limitation of the paper is the lack of control variables at the country level given the scarce number of nations that are surveyed. Lastly, we are only able to measure informality indirectly through the lack of work contracts. While this is a reasonable method of operationalization according to legalistic approach, there are other definitions of informal employment in the literature. Particularly, the formal-informal divide among the self-employed and informal enterprises are not possible to detect from the survey. 


\section{References}

Acar, E.O. and A. Tansel (2016). "Defining and Measuring Informality: The Case of Turkish Labor Market”. Sosyoekonomi, 24(28), 147-174.

Angel-Urdinola, D. and Tanabe, K. (2012). "Micro-Determinants of Informal Employment in The Middle East and North Africa Region". WB Social Protection and Labor Discussion Paper, No. 1201.

Angrist, J.D. and Pischke, J.S. (2008). Mostly Harmless Econometrics: An Empiricist's Companion, Princeton, NJ: Princeton University Press.

Baker, A. and Velasco-Guachalla, V.X. (2018). "Is the Informal Sector Politically Different? (Null) Answers from Latin America”. World Development, 108: 170-182.

Benstead, L.J., Atkeson. L.R. and Shahid, M.A. (2019). "Does wasta undermine support for democracy? Corruption, clientelism, and attitudes toward political regimes”. In I. Kubbe and A. Varraich (eds). Corruption and Informal Practices in the Middle East and North Africa. London: Routledge, pp. 77-101.

Berens, S. (2015a). "Preferences on redistribution in fragmented labor markets in Latin America and the Caribbean". Journal of Politics in Latin America, 7(3): 117-156.

Berens, S. (2015b). "Between Exclusion and Calculating Solidarity? Preferences for Private Versus Public Welfare Provision and the Size of the Informal Sector". Socio-Economic Review, 13(4): 651-678.

Bourhaba O. and Hamimida M. (2016). “An estimation of the informal economy in Morocco". International Journal of Economics and Finance, 8(9): 140-147. 
Castells, M. and A. Portes. (1989). "World Underneath: The Origins, Dynamics and Effects of the Informal Economy". In A. Portes, M. Castells and L.A. Benton (eds). The Informal Economy: Studies in Advanced and Less Developed. Baltimore, MD: John Hopkins University Press, pp. 11-37

Chen, M.A. (2012). “The informal economy: Definitions, theories and policies". WIEGO Working Paper, Vol. 1, No. 26.

Davis, D.E. (1994). Urban Leviathan: Mexico City in the Twentieth Century. Philadelphia, PI: Temple University Press.

de Soto, H. (1989). The Other Path: The Invisible Revolution in the Third World, New York, NY: Harper \& Row.

Duman, A. (2020). "Pay Gaps and Mobility for Lower and Upper Tier Informal Sector Employees: an investigation of the Turkish labor market". GLO Discussion Paper, No. 655.

Duman, A. (forthcoming) "Mixed Perceptions of State Responsibility among Informal Sector Participants in MENA". In A. Polese (ed.) Informality, Development and the State, London: Palgrave.

Elsayed, A. and Wahba, J. (2019). "Political change and informality: Evidence from the Arab Spring”. The Economics of Transition, 27(1): 31-66.

Gerxhani, K. (2003). “Tax Evasion in Transition: Outcome of an Institutional Clash? Testing Feige's Conjecture in Albania”. European Economic Review, 48: 729-745.

Hirschman, A.O. (1970). Exit, Voice, and Loyalty: Responses to Decline in Firms, Organizations and States. Cambridge, MA: Harvard University Press. 
Hussmanns, R. (2005). "Measuring the Informal Economy: From Employment in the Informal Sector to Informal Employment”. ILO Policy Integration Department Working Paper, No. 53.

Holtmeier, L. and Alami, M. 2020. "Informal workers in Arab world hit hardest by coronavirus, unlikely to get help". Available at: https://english.alarabiya.net/en/features/2020/04/03/Informal-workers-in-Arab-world-hit-hardestby-coronavirus-unlikely-to-get-help. Accessed [21 February 2020].

Ivlevs, A. (2016). “Remittances and Informal Work”. IZA Discussion Papers, No. 10196.

Justino, P. and Shemyakina, O.N. (2012). "Remittances and Labour Supply in Post-Conflict Tajikistan”. IZA Journal of Labour and Development, 1: 1-28.

Kanbur, R. (2017). “Informality: Causes, consequences and policy responses". Review of Development Economics, 21(4): 939-961.

Kurtz, M. (2004). "The dilemmas of democracy in the open economy". World Politics, 56(2): $262-302$.

Lehmann, H. (2012). Labor Market Institutions and Informality in Transition and Latin American Countries. Bologna: University of Bologna.

Lewis, W.A. (1955). The Theory of Economic Growth. London: George Allen \& Unwin Ltd.

Loayza, N., and Wada, T. (2011). "Informal Labor in the Middle East and North Africa: Basic Measures and Determinants". Available at: http://documents1.worldbank.org/curated/en/657651468052140219/pdf/675900WP0P11320y0pa per0text09021011.pdf. Accessed [10 January 2021].

Medina, L. and Schneider, F. (2018). "Shadow Economies Around the World: What Did We Learn Over the Last 20 Years”. IMF Working Paper, No. 18/17. 
Ordonez, J. (2014). “Tax Collection, the Informal Sector, and Productivity”. Review of Economic Dynamics, 17(2): 262-286.

Perry, G.E., Maloney, W.F., Arias, O.S., Fajnzylber, P., Mason, A.D. and SaavedraChanduvi, J. (2007). Informality: Exit and Exclusion. Washington, DC: World Bank.

Portes, A. and Hoffman, K. (2003). "Latin American class structures: Their composition and change during the neoliberal era". Latin American Research Review, 38(1):41-82.

Posso, A. (2012). "Remittances and Aggregate Labour Supply: Evidence from 66 Developing Nations". Developing Economies, 50(1): 25-39.

Saavedra, J. and Tommasi, M. (2007). "Informality, the State and the Social Contract in Latin America: a preliminary exploration". International Labour Review, 146(3-4): 279-309.

Schneider, F. (2012). "The Shadow Economy and Work in the Shadow: What Do We (Not) Know?”. IZA Discussion Papers, No. 6423.

Trabelsi, K. (2013) "Current state of the informal economy in Tunisia as seen by its stakeholders: Facts and alternatives". Available at: https://www.solidaritycenter.org/publication/current-state-of-the-informal-economy-in-tunisiaas-seen-through-its-stakeholders-facts-and-alternatives-june-2014/. Accessed [10 January 2021].

Vuletin, G. (2008). "Measuring the Informal Economy in Latin America and the Caribbean". IMF Working Paper, No. 08/102.

Wooldridge, J. M. (2010). Econometric Analysis of Cross Section and Panel Data, 2nd ed. Cambridge, MA: MIT Press.

World Bank. 2019. "Growing in the Shadow: challenges of informality". In Global Economic Prospects, Washington, DC: World Bank, pp. 129-195. 


\section{Appendix}

Table A1. Share of Responses by Country (\%)

\begin{tabular}{|c|c|c|c|c|c|c|c|c|c|c|c|c|}
\hline & Algeria & Egypt & Iraq & Jordan & Kuwait & Lebanon & Libya & Morocco & Palestine & Sudan & Tunisia & Yemen \\
\hline \multicolumn{13}{|c|}{$\begin{array}{l}\text { Corruption: Extent } \\
\text { National Level }\end{array}$} \\
\hline Large Extent & 0.00 & 37.88 & 75.63 & 58.32 & 44.57 & 59.83 & 77.14 & 41.08 & 49.33 & 49.18 & 76.20 & 34.08 \\
\hline Medium Extent & 0.00 & 41.88 & 18.36 & 32.47 & 40.77 & 31.48 & 15.84 & 30.90 & 36.01 & 31.62 & 17.71 & 39.52 \\
\hline Small Extent & 0.00 & 16.94 & 3.79 & 6.75 & 11.98 & 7.56 & 4.85 & 23.37 & 12.56 & 16.34 & 3.31 & 23.41 \\
\hline No Extent & 0.00 & 3.30 & 2.22 & 2.45 & 2.68 & 1.13 & 2.17 & 4.66 & 2.09 & 2.86 & 2.79 & 2.99 \\
\hline \multicolumn{13}{|c|}{ Trust: Government } \\
\hline Great Trust & 0.00 & 31.64 & 4.17 & 7.53 & 13.52 & 1.67 & 1.96 & 8.71 & 4.39 & 7.30 & 4.63 & 33.01 \\
\hline Some Trust & 0.00 & 41.06 & 15.21 & 32.43 & 35.54 & 17.17 & 8.59 & 23.60 & 30.89 & 27.80 & 17.06 & 24.72 \\
\hline Little Trust & 0.00 & 17.08 & 16.67 & 24.30 & 27.05 & 34.17 & 23.05 & 29.87 & 28.82 & 34.81 & 16.53 & 23.62 \\
\hline No Trust & 0.00 & 10.22 & 63.96 & 35.73 & 23.89 & 46.99 & 66.40 & 37.83 & 35.91 & 30.08 & 61.78 & 18.65 \\
\hline \multicolumn{13}{|l|}{$\begin{array}{l}\text { Creating Job } \\
\text { Opportunities }\end{array}$} \\
\hline Very Good & 0.40 & 5.19 & 0.57 & 0.67 & 7.64 & 0.38 & 3.62 & 3.87 & 1.59 & 2.43 & 1.99 & 6.57 \\
\hline Good & 11.21 & 25.54 & 5.48 & 13.12 & 42.66 & 3.91 & 18.04 & 21.05 & 12.08 & 18.17 & 16.27 & 24.32 \\
\hline $\mathrm{Bad}$ & 42.47 & 43.64 & 26.06 & 26.41 & 36.56 & 36.25 & 44.44 & 37.16 & 40.89 & 42.36 & 32.84 & 38.74 \\
\hline Very Bad & 45.92 & 25.63 & 67.88 & 59.80 & 13.14 & 59.47 & 33.90 & 37.92 & 45.44 & 37.04 & 48.90 & 30.38 \\
\hline \multicolumn{13}{|c|}{$\begin{array}{l}\text { Narrowing Gap } \\
\text { Between Rich and Poor }\end{array}$} \\
\hline Very Good & 0.55 & 4.09 & 1.67 & 0.73 & 5.13 & 0.51 & 2.51 & 3.25 & 1.34 & 2.62 & 1.84 & 11.55 \\
\hline Good & 9.91 & 32.11 & 12.43 & 12.15 & 34.99 & 3.67 & 15.90 & 18.76 & 16.09 & 17.00 & 12.41 & 23.63 \\
\hline $\mathrm{Bad}$ & 49.35 & 44.96 & 35.96 & 33.11 & 42.65 & 40.48 & 47.71 & 40.98 & 48.55 & 48.63 & 35.79 & 37.47 \\
\hline Very Bad & 40.18 & 18.84 & 49.94 & 54.02 & 17.22 & 55.34 & 33.88 & 37.01 & 34.02 & 31.75 & 49.96 & 27.35 \\
\hline
\end{tabular}


Table A2. Summary Statistics

\begin{tabular}{|c|c|c|c|c|c|}
\hline Variable & Obs & Mean & Std. Dev. & Min & Max \\
\hline Corruption & 23802 & 1.621 & .795 & 1 & 4 \\
\hline Trust & 23704 & 2.929 & 1.037 & 1 & 4 \\
\hline Job creation & 26090 & 3.217 & .815 & 1 & 4 \\
\hline Narrowing gap between rich and poor & 25025 & 3.164 & .801 & 1 & 4 \\
\hline Formal & 26672 & .09 & .287 & 0 & 1 \\
\hline Informal & 26780 & .086 & .28 & 0 & 1 \\
\hline Self-employed & 26672 & .137 & .344 & 0 & 1 \\
\hline Education & 26743 & 2.167 & 1.344 & 0 & 4 \\
\hline Gender & 26748 & .498 & .5 & 0 & 1 \\
\hline Married & 26780 & .596 & .491 & 0 & 1 \\
\hline Rural & 26780 & .309 & .462 & 0 & 1 \\
\hline Statist & 25880 & .39 & .488 & 0 & 1 \\
\hline Religiosity & 24941 & .359 & .48 & 0 & 1 \\
\hline Remittances & 12516 & .143 & .35 & 0 & 1 \\
\hline Age & 26664 & 38.59 & 14.907 & 17 & 95 \\
\hline Income & 20439 & 6.545 & 3.127 & 1 & 12 \\
\hline \# of Employed in the $\mathrm{HH}$ & 26639 & 1.847 & 1.342 & 0 & 9 \\
\hline
\end{tabular}


Table A3. Reduced Form Regressions by Employment Type

\begin{tabular}{|c|c|c|c|}
\hline & Informal & Formal & Self-Employed \\
\hline \multirow[t]{2}{*}{ Remittances } & $0.28^{* *}$ & 0.06 & -0.06 \\
\hline & $(0.07)$ & $(0.06)$ & $(0.06)$ \\
\hline \multirow[t]{2}{*}{ Age } & $0.01 * *$ & $0.01 * *$ & $0.02 * *$ \\
\hline & $(0.00)$ & $(0.00)$ & $(0.00)$ \\
\hline \multirow[t]{2}{*}{ Gender } & $0.11 *$ & $0.17 * *$ & $-0.56 * *$ \\
\hline & $(0.04)$ & $(0.04)$ & $(0.04)$ \\
\hline \multirow[t]{2}{*}{ Primary } & 0 & 0 & 0 \\
\hline & (.) & (.) & (.) \\
\hline \multirow[t]{2}{*}{ Secondary } & $0.37 * *$ & 0.26 & -0.03 \\
\hline & $(0.12)$ & $(0.14)$ & $(0.09)$ \\
\hline \multirow[t]{2}{*}{ High } & $0.38^{* *}$ & $0.67 * *$ & -0.04 \\
\hline & $(0.12)$ & $(0.14)$ & $(0.09)$ \\
\hline \multirow[t]{2}{*}{ University } & $0.78^{* *}$ & $0.75^{* *}$ & $-0.40 * *$ \\
\hline & $(0.13)$ & $(0.14)$ & $(0.10)$ \\
\hline \multirow[t]{2}{*}{ Rural } & $0.73^{* *}$ & $1.21 * *$ & $-0.67 * *$ \\
\hline & $(0.12)$ & $(0.14)$ & $(0.09)$ \\
\hline \multirow[t]{2}{*}{ \# of Employed } & $-0.18 * *$ & $-0.13 * *$ & 0.04 \\
\hline & $(0.05)$ & $(0.05)$ & $(0.04)$ \\
\hline \multirow[t]{2}{*}{ Constant } & 0.02 & $0.05 * *$ & $0.10 * *$ \\
\hline & $(0.02)$ & $(0.02)$ & $(0.02)$ \\
\hline Pseudo R-squared & 0.1 & 0.1 & 0.2 \\
\hline $\mathbf{N}$ & 5715 & 5715 & 5715 \\
\hline
\end{tabular}


Table A4. Full IV Ordered Probit Regressions

\begin{tabular}{|c|c|c|c|c|}
\hline & Corruption & Trust & Job Creation & Redistribution \\
\hline \multirow[t]{2}{*}{ Informal } & $1.05 * *$ & $1.19 * *$ & $1.12 * *$ & $0.74 *$ \\
\hline & $(0.16)$ & $(0.13)$ & $(0.12)$ & $(0.36)$ \\
\hline \multirow[t]{2}{*}{ Age } & 0 & 0 & $-0.01 * *$ & 0 \\
\hline & $(0.00)$ & $(0.00)$ & $(0.00)$ & $(0.00)$ \\
\hline \multirow[t]{2}{*}{ Gender } & -0.04 & $-0.09 *$ & $-0.12 * *$ & $-0.15 * *$ \\
\hline & $(0.04)$ & $(0.04)$ & $(0.04)$ & $(0.04)$ \\
\hline \multirow{2}{*}{ Primary } & $0.24 *$ & 0.19 & 0.15 & $0.38 * *$ \\
\hline & $(0.12)$ & $(0.12)$ & $(0.11)$ & $(0.14)$ \\
\hline \multirow[t]{2}{*}{ Secondary } & 0.17 & 0.09 & 0.02 & $0.28 *$ \\
\hline & $(0.11)$ & $(0.12)$ & $(0.11)$ & $(0.14)$ \\
\hline \multirow[t]{2}{*}{ High } & 0.17 & 0.09 & -0.11 & 0.18 \\
\hline & $(0.13)$ & $(0.13)$ & $(0.12)$ & $(0.16)$ \\
\hline \multirow[t]{2}{*}{ University } & $0.28 *$ & 0.06 & -0.11 & 0.2 \\
\hline & $(0.13)$ & $(0.13)$ & $(0.11)$ & $(0.16)$ \\
\hline \multirow[t]{2}{*}{ Married } & 0 & -0.05 & $-0.08 *$ & $-0.13 * *$ \\
\hline & $(0.04)$ & $(0.04)$ & $(0.03)$ & $(0.04)$ \\
\hline \multirow[t]{2}{*}{ Rural } & -0.01 & $-0.19 * *$ & 0.07 & $-0.11 *$ \\
\hline & $(0.04)$ & $(0.04)$ & $(0.04)$ & $(0.05)$ \\
\hline \multirow[t]{2}{*}{ Statist } & $-0.50 * *$ & $-0.64 * *$ & $-0.45 * *$ & $-0.55 * *$ \\
\hline & $(0.04)$ & $(0.04)$ & $(0.04)$ & $(0.05)$ \\
\hline \multirow[t]{2}{*}{ Religious } & $-0.08^{*}$ & $-0.09 * *$ & 0.01 & $-0.10 * *$ \\
\hline & $(0.04)$ & $(0.03)$ & $(0.03)$ & $(0.04)$ \\
\hline \multirow[t]{2}{*}{ \# of Employed } & -0.02 & $-0.03 *$ & -0.03 & -0.03 \\
\hline & $(0.02)$ & $(0.02)$ & $(0.02)$ & $(0.02)$ \\
\hline \multirow[t]{2}{*}{ Income } & $-0.03 * *$ & $-0.02 * *$ & 0 & 0 \\
\hline & $(0.01)$ & $(0.01)$ & $(0.01)$ & $(0.01)$ \\
\hline \multicolumn{5}{|l|}{$\begin{array}{l}\text { Instrumented } \\
\text { (Informal) }\end{array}$} \\
\hline \multirow[t]{2}{*}{ Remittances } & $0.35 * *$ & $0.32 * *$ & $0.30 * *$ & $0.32 * *$ \\
\hline & $(0.07)$ & $(0.07)$ & $(0.06)$ & $(0.08)$ \\
\hline \multirow[t]{2}{*}{ Age } & $0.01 * *$ & $0.01 * *$ & $0.01 * *$ & $0.01 * *$ \\
\hline & $(0.00)$ & $(0.00)$ & $(0.00)$ & $(0.00)$ \\
\hline \multirow[t]{2}{*}{ Gender } & $0.14 * *$ & $0.15^{* *}$ & $0.14 * *$ & $0.12 *$ \\
\hline & $(0.05)$ & $(0.05)$ & $(0.05)$ & $(0.05)$ \\
\hline \multirow[t]{2}{*}{ Primary } & $0.81 * *$ & $0.73 * *$ & $0.54 * *$ & $0.64 * *$ \\
\hline & $(0.26)$ & $(0.23)$ & $(0.19)$ & $(0.21)$ \\
\hline \multirow[t]{2}{*}{ Secondary } & $0.84 * *$ & $0.77 * *$ & $0.60 * *$ & $0.67 * *$ \\
\hline & $(0.26)$ & $(0.23)$ & $(0.19)$ & $(0.20)$ \\
\hline \multirow[t]{2}{*}{ High } & $1.21 * *$ & $1.13^{* *}$ & $0.92 * *$ & $1.01 * *$ \\
\hline & $(0.26)$ & $(0.23)$ & $(0.20)$ & $(0.21)$ \\
\hline \multirow[t]{2}{*}{ University } & $1.16^{* *}$ & $1.07 * *$ & $0.89 * *$ & $1.00 * *$ \\
\hline & $(0.26)$ & $(0.23)$ & $(0.19)$ & $(0.20)$ \\
\hline Rural & $-0.21 * *$ & $-0.22 * *$ & $-0.19 * *$ & $-0.22 * *$ \\
\hline
\end{tabular}




\begin{tabular}{|l|c|c|c|c|}
\hline & $(0.05)$ & $(0.05)$ & $(0.05)$ & $(0.06)$ \\
\hline \# of Employed & 0.03 & 0.03 & 0.03 & 0.03 \\
\hline & $(0.02)$ & $(0.02)$ & $(0.02)$ & $(0.02)$ \\
\hline Constant & $-2.57^{* *}$ & $-2.42^{* *}$ & $-2.31^{* *}$ & $-2.37^{* *}$ \\
\hline & $(0.29)$ & $(0.26)$ & $(0.22)$ & $(0.23)$ \\
\hline \# of Obs. & 4070 & 4058 & 4416 & 4295 \\
\hline Corr. & $-0.6^{* *}$ & $-0.68^{* *}$ & $-0.76^{* *}$ & $-0.45^{*}$ \\
\hline & $(0.1)$ & $(0.08)$ & $(0.07)$ & $(0.21)$ \\
\hline
\end{tabular}

Notes: The reference category is labor market participations who are not informal. Robust standard errors are in parenthesis. ${ }^{* *}$ and $*$ denote statistical significance at the .01 and .05 levels, respectively. 
Table A5. Estimation Results after Resampling

\begin{tabular}{|c|c|c|c|c|c|}
\hline & & Corruption & Trust & Job Creation & $\overline{\text { Redistribution }}$ \\
\hline \multirow[t]{2}{*}{ No Outlier } & Informal & $\begin{array}{c}0.87 * * \\
(0.29)\end{array}$ & $\begin{array}{c}1.07 * * \\
(0.16)\end{array}$ & $\begin{array}{l}1.27 * * \\
(0.09)\end{array}$ & $\begin{array}{c}0.96 * * \\
(0.35)\end{array}$ \\
\hline & Corr. & $\begin{array}{c}-0.50 * * \\
(0.17) \\
3501\end{array}$ & $\begin{array}{c}-0.66^{* *} \\
(0.09) \\
3499\end{array}$ & $\begin{array}{c}-0.80 * * \\
(0.06) \\
3852\end{array}$ & $\begin{array}{c}-0.56 * * \\
(0.21) \\
3745\end{array}$ \\
\hline \multirow[t]{2}{*}{ Same Countries } & Temporary & $\begin{array}{l}1.05^{* *} \\
(0.29)\end{array}$ & $\begin{array}{l}1.19 * * \\
(0.16)\end{array}$ & $\begin{array}{l}1.04 * * \\
(0.12)\end{array}$ & $\begin{array}{c}0.74 * * \\
(0.33)\end{array}$ \\
\hline & Corr. & $\begin{array}{c}-0.60 * * \\
(0.1) \\
4070\end{array}$ & $\begin{array}{c}-0.68 * * \\
(0.08) \\
4058\end{array}$ & $\begin{array}{c}-0.72 * * \\
(0.1) \\
4050\end{array}$ & $\begin{array}{c}-0.44 * * \\
(0.19) \\
3945\end{array}$ \\
\hline
\end{tabular}

Notes: The reference category is labor market participations who are not informal. Robust standard errors are in parenthesis. ${ }^{* *}$ and $*$ denote statistical significance at the .01 and .05 levels, respectively. 
Table A6. Binary Dependent Variables

\begin{tabular}{|c|c|c|c|c|}
\hline & Corruption & Trust & Job Creation & Redistribution \\
\hline \multirow[t]{2}{*}{ Informal } & $1.34 * *$ & $0.76^{* *}$ & $1.24 * *$ & $1.28^{* *}$ \\
\hline & $(0.14)$ & $(0.27)$ & $(0.22)$ & $(0.19)$ \\
\hline \multirow[t]{2}{*}{ Age } & 0 & 0 & $-0.01 * *$ & 0 \\
\hline & $(0.00)$ & $(0.00)$ & $(0.00)$ & $(0.00)$ \\
\hline \multirow[t]{2}{*}{ Gender } & $-0.11^{*}$ & $-0.12 *$ & $-0.15^{* *}$ & $-0.19 * *$ \\
\hline & $(0.05)$ & $(0.05)$ & $(0.05)$ & $(0.05)$ \\
\hline \multirow[t]{2}{*}{ Primary } & 0.07 & $0.39 * *$ & 0.13 & 0.3 \\
\hline & $(0.16)$ & $(0.14)$ & $(0.18)$ & $(0.17)$ \\
\hline \multirow[t]{2}{*}{ Secondary } & 0.16 & $0.31 *$ & -0.04 & 0.18 \\
\hline & $(0.16)$ & $(0.14)$ & $(0.16)$ & $(0.16)$ \\
\hline \multirow[t]{2}{*}{ High } & -0.07 & $0.44 * *$ & -0.16 & -0.02 \\
\hline & $(0.18)$ & $(0.17)$ & $(0.20)$ & $(0.18)$ \\
\hline \multirow[t]{2}{*}{ University } & 0.03 & $0.38^{*}$ & -0.18 & 0.03 \\
\hline & $(0.18)$ & $(0.16)$ & $(0.19)$ & $(0.18)$ \\
\hline \multirow[t]{2}{*}{ Married } & 0.06 & -0.08 & -0.05 & $-0.16^{* *}$ \\
\hline & $(0.05)$ & $(0.05)$ & $(0.04)$ & $(0.05)$ \\
\hline \multirow[t]{2}{*}{ Rural } & 0.03 & $-0.26 * *$ & 0.06 & -0.01 \\
\hline & $(0.06)$ & $(0.06)$ & $(0.06)$ & $(0.06)$ \\
\hline \multirow[t]{2}{*}{ Statist } & $-0.42 * *$ & $-0.78 * *$ & $-0.52 * *$ & $-0.59 * *$ \\
\hline & $(0.06)$ & $(0.06)$ & $(0.11)$ & $(0.11)$ \\
\hline \multirow[t]{2}{*}{ Religious } & $-0.10 *$ & $-0.15 * *$ & -0.02 & $-0.12 * *$ \\
\hline & $(0.05)$ & $(0.05)$ & $(0.04)$ & $(0.04)$ \\
\hline \multirow[t]{2}{*}{ \# of Employed } & -0.02 & -0.03 & $-0.06 * *$ & $-0.06 * *$ \\
\hline & $(0.02)$ & $(0.02)$ & $(0.02)$ & $(0.02)$ \\
\hline \multirow[t]{2}{*}{ Income } & $-0.03 * *$ & $-0.03 * *$ & 0.01 & 0 \\
\hline & $(0.01)$ & $(0.01)$ & $(0.01)$ & $(0.01)$ \\
\hline \multirow[t]{2}{*}{ Corr. } & $-0.78 * *$ & $-0.43 * *$ & $-0.84 * *$ & $-0.83 * *$ \\
\hline & $(0.1)$ & $(0.16)$ & $(0.16)$ & $(0.14)$ \\
\hline \# of Obs. & 4070 & 4058 & 4416 & 4295 \\
\hline
\end{tabular}

Notes: The reference category is labor market participations who are not informal. Robust standard errors are in parenthesis. ${ }^{* *}$ and $*$ denote statistical significance at the .01 and .05 levels, respectively. 
Figure A1. Composition of Labor Force and Inactive Population
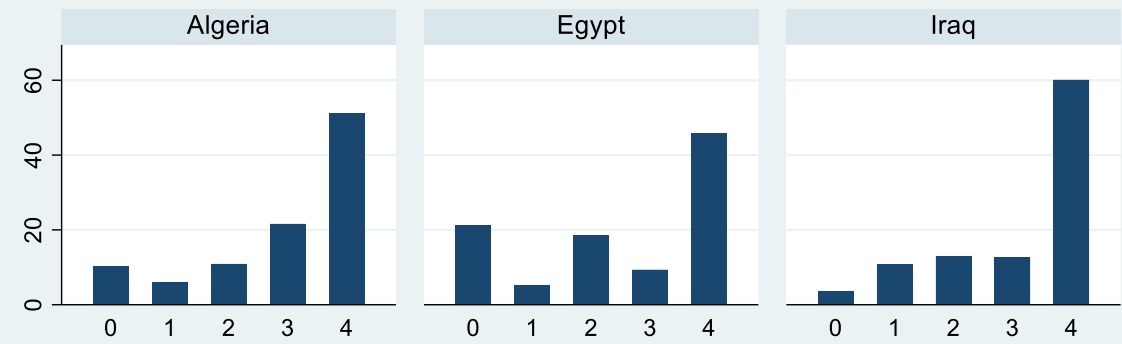

Libya

Morocco
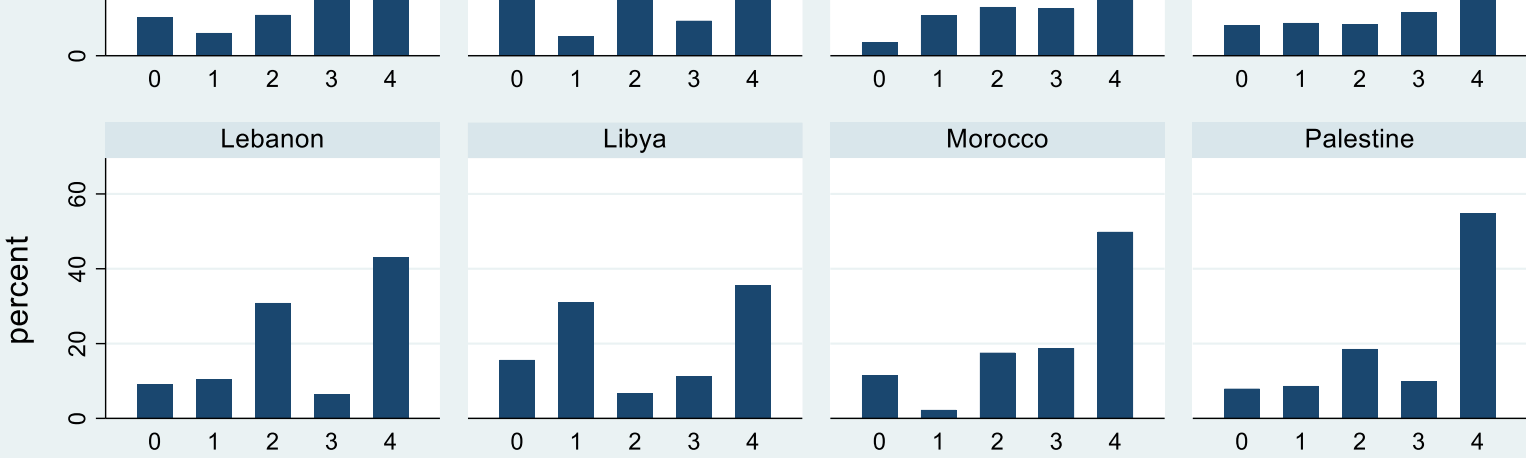

Palestine



Tunisia

Yemen
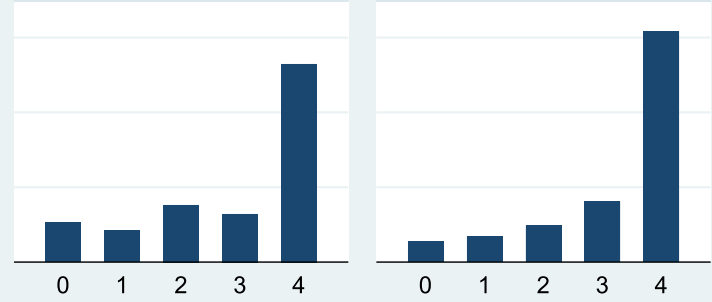

Notes: 0, 1, 2, 3, 4 represent informal, formal, self-employed, unemployed, and non-employed respectively. 
Figure A2. Remittances by Country

Figure A3. Marginal Effects of Broad Measure of Informality on Corruption and Trust

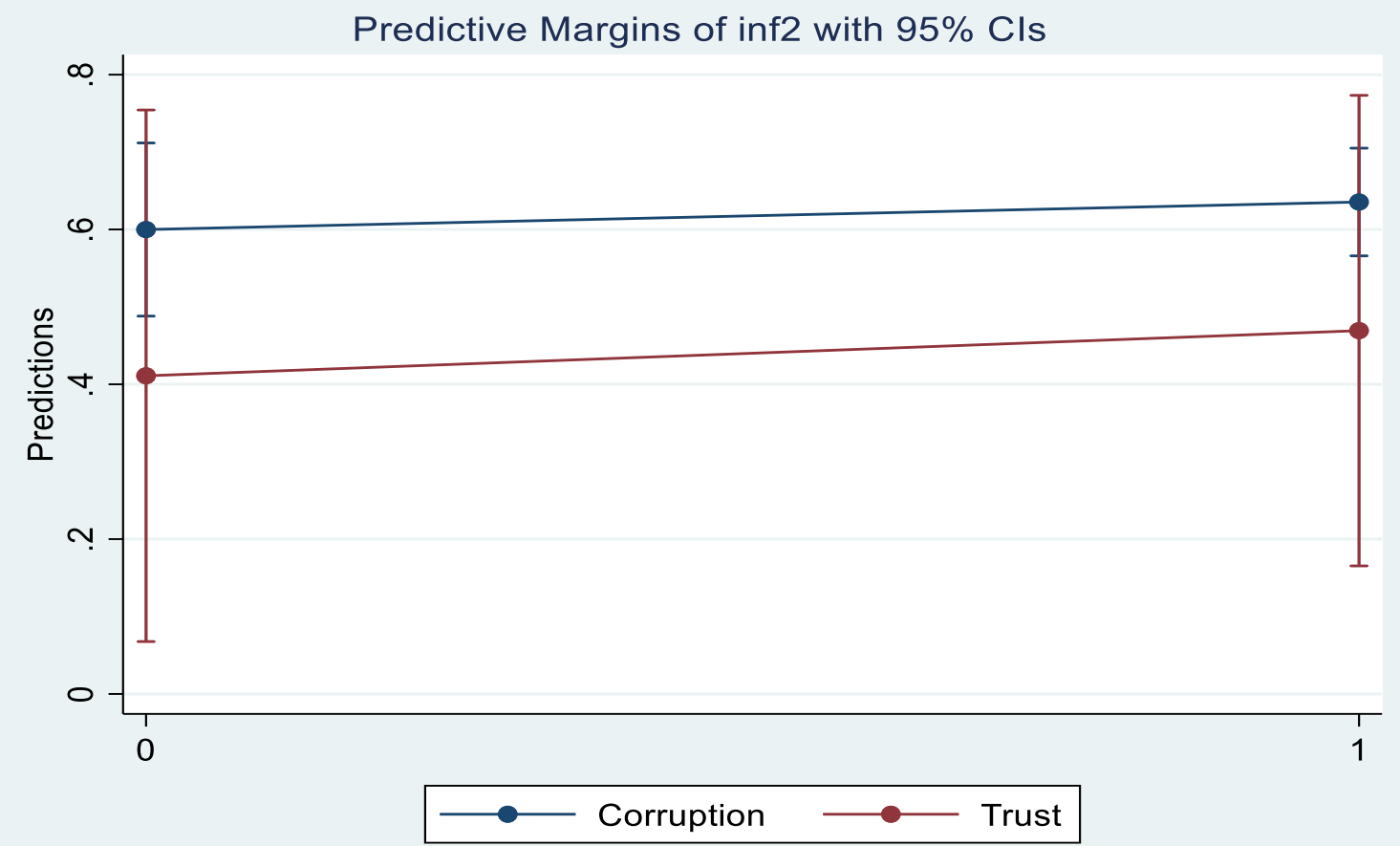

Source: Marginal effects are estimated at covariate means and based on the eoprobit estimations. The outcome level (4) is great extent of corruption and no trust. 
Figure A4. Marginal Effects of Broad Measure of Informality on Job Creation and Redistribution

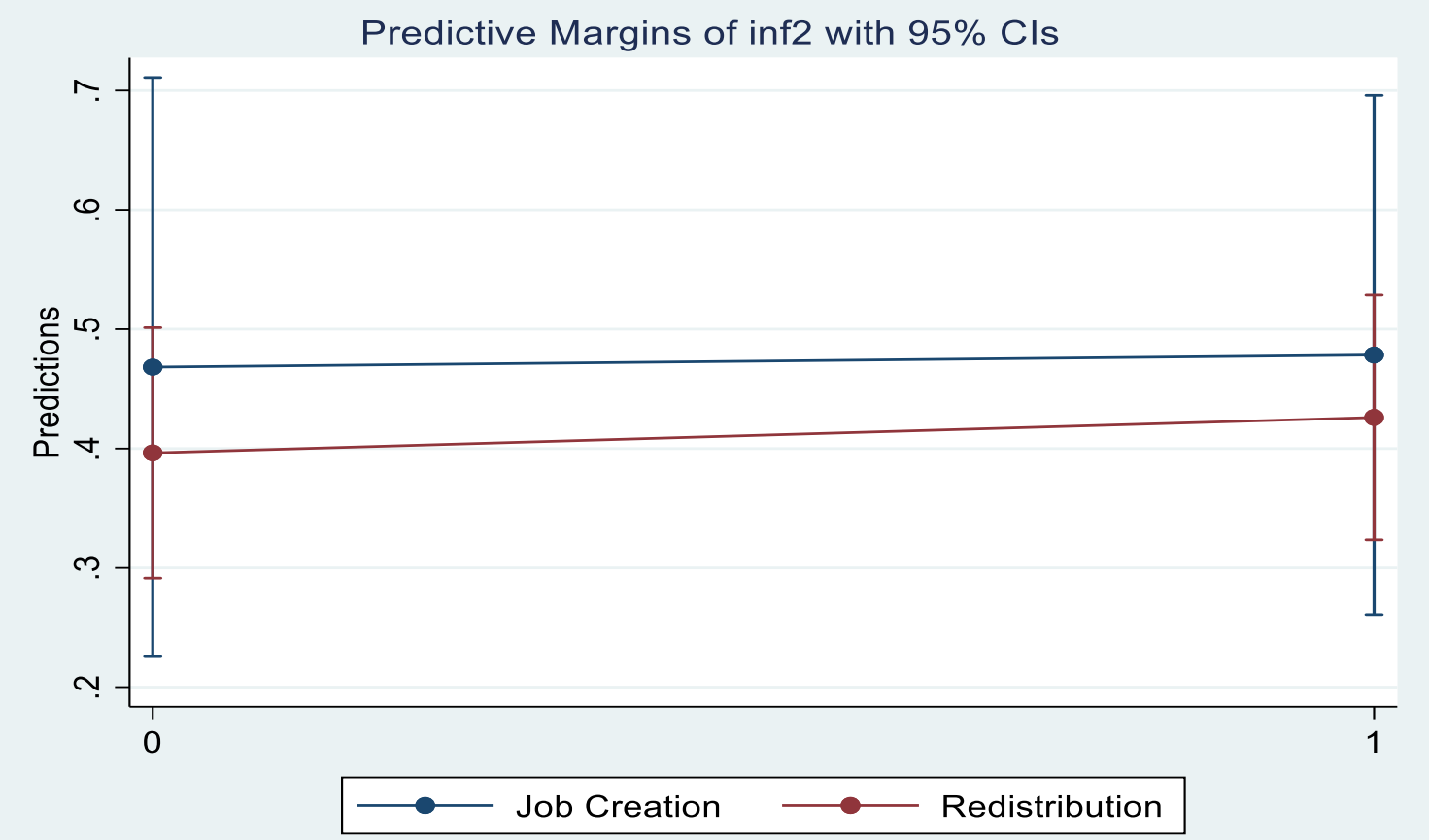

Source: Marginal effects are estimated at covariate means and based on the eoprobit estimations. The outcome level (4) is very bad for job creation and very bad for narrowing the gap between rich and poor. 


\footnotetext{
${ }^{i}$ These countries are Algeria, Egypt, Iraq, Jordan, Kuwait, Lebanon, Libya, Morocco, Palestine, Sudan, Tunisia and Yemen.

ii For technical details, see https://www.arabbarometer.org/.

iii For example, in Kuwait the share of informal sector is estimated to be between 20-30\%, which is quite lower than the rest of the Arab countries. Additionally, Gulf countries have a considerable share of immigrant workers, mostly employed in the low skilled sector jobs that are often filled by informal workers elsewhere. For more details, see Medina and Schneider (2018).

iv Own-account workers and employers working in their own informal sector enterprises are counted as informal by various researchers. For more detail, see Hussmans (2005).

${ }^{v}$ Same instrumental variable is utilized in the probit estimations to follow a two-stage estimation methodology.

${ }^{\text {vi }}$ Reduced form equations for informal employment, formal employment and self-employment are presented in Table A3 in the Appendix.

vii For brevity the results for weak identification, over identification and bivariate probit results are not presented but can be asked from the author.

viii Full tables for IV estimations are presented in TableA4 in the Appendix.

${ }^{\text {ix }}$ There are no observations for corruption in Algeria and Yemen has very few observations on all covariates when trust if the dependent variable.
} 